\title{
The Role of Arbuscular Mycorrhiza Fungi in the Decomposition of Fresh Residue and Soil Organic Carbon : A Mini-Review
}

\author{
Wei, Lili
}

2019

Wei , L , Vosatka , M , Cai , B , Ding , J , Lu , C , Xu , J , Yan , W , Li , Y \& Liu , C 2019 , ' The Role of Arbuscular Mycorrhiza Fungi in the Decomposition of Fresh Residue and Soil Organic Carbon : A Mini-Review ' , Soil Science Society of America Journal , vol. 83 , no. 3 , pp. 511-517 . https://doi.org/10.2136/sssaj2018.05.0205

http://hdl.handle.net/10138/322495

https://doi.org/10.2136/sssaj2018.05.0205

acceptedVersion

Downloaded from Helda, University of Helsinki institutional repository.

This is an electronic reprint of the original article.

This reprint may differ from the original in pagination and typographic detail.

Please cite the original version. 
1 The Role of Arbuscular Mycorrhiza Fungi in the Decomposition of Fresh Residue and Soil

2 Organic Carbon: A Mini-Review

4 Lili Wei ${ }^{1 *}$, Miroslav Vosátka ${ }^{2}$, Bangping Cai ${ }^{3}$, Jing Ding ${ }^{1}$, Changyi $\mathrm{Lu}^{4}$, Jinghua $\mathrm{Xu}^{5}$, Wenfei

5 Yan ${ }^{1}$, Yuhong $\mathrm{Li}^{6}$, Chaoxiang Liu ${ }^{1 *}$

6

7 1. Institute of Urban Environment, Chinese Academy of Science, Xiamen 361021, China

8 2. Institute of Botany, The Czech Academy of Sciences, 25243 Pruhonice, Czech Republic

9 3. Xiamen Botanical Garden, Xiamen 361003, China

10 4. Faculty of Biological and, Environmental Sciences, Ecosystems and Environment Research

11 Programme, University of Helsinki, FI-15140 Lahti, Finland

5. Quanzhou Normal University, Quanzhou 362000, China

13 6. Department of Environmental Science and Engineering, Huaqiao University, Xiamen 361021, 14 China

$15 *$ *Corresponding author (1.l.wei@ hotmail.com, cxliu@iue.ac.cn) 
3 6

\section{Abstract}

Arbuscular mycorrhizal fungi (AMF) are widespread in terrestrial ecosystems. In addition to their contributions to plant nutrient uptake, AMF also provide many ecological functions including regulation of soil $\mathrm{C}$ dynamics. However, both stimulating and retarding soil organic decomposition by AMF have been observed. Here we discuss the possible reasons for such a contradiction. Arbuscular mycorrhizal fungi contribute to soil aggregation mainly through hyphal enmeshment, saprotrophic suppression, and production of glomalin-related soil proteins, while AMF can also stimulate organic decomposition through promoting degradative enzymes, modifying root production and activity, and/or through regulating the microbial community in the mycorrhizosphere and hyphosphere. The role of AMF in $\mathrm{C}$ decomposition is strongly dependent on the quality and quantity of different soil $\mathrm{C}$ pools. Arbuscular mycorrhizal fungi can stimulate fresh residue decomposition initially through stimulating the decomposition of fresh residues (particularly those having high $\mathrm{C} / \mathrm{N}$ ratio), whereas for older or decomposed soil organic $\mathrm{C}$, AMF tend to suppress decomposition by promoting soil aggregation. Under elevated $\mathrm{CO}_{2}\left(\mathrm{eCO}_{2}\right), \mathrm{AMF}$ show additive effects on residue decomposition, priming effects, and changes in soil aggregation. Despite organic decomposition rates differing in the short term and long term following litter experiments, our discussion highlights the role of $\mathrm{AMF}$ in organic $\mathrm{C}$ dynamics. We hypothesize that $\mathrm{AMF}$ would benefit soil $\mathrm{C}$ gain in the long term and thereby predict that disturbances that impacts negatively on AMF, such as tillage, residue burning, fertilization, and fungicide application, would lead to soil $\mathrm{C}$ decline particularly under eCO 2 . 
Soil is the major long-term C pool in terrestrial ecosystems (60). A shift in the decomposition rate of soil C could lead to profound changes in ecosystem C storage (29). Arbuscular mycorrhizal fungi are associated with greater than 200,000 plant species, including most herbs and grasses, and many trees and hornworts, representing more than $80 \%$ of terrestrial plant species (66). Notably, under elevated atmospheric $\mathrm{CO}_{2}\left(\mathrm{eCO}_{2}\right)$, the growth of $\mathrm{AMF}$ and their colonization rate generally increase $(17 ; 11)$. Given their ubiquitous distribution and their capacity in controlling soil $\mathrm{C}$ dynamics $(50 ; 72 ; 11 ; 10)$, understanding how AMF influence soil $\mathrm{C}$ balance is crucial to predict future global $\mathrm{C}$ dynamics. However, studies have observed both stimulating and retarding effects on organic $\mathrm{C}$ decomposition by AMF presentation. To untangle the contradiction, we focused our discussion on different C poolsfresh residues and old soil organic $\mathrm{C}$. We also included litter quality $(\mathrm{C} / \mathrm{N}$ ratio) and climate change effects in our discussion given their intimate involvement in the regulation of organic $\mathrm{C}$ pools.

\section{THE ROLE OF ARBUSCULAR MYCORRHIZAL FUNGI IN ORGANIC DECOMPOSITION}

\section{Contribution to Soil Aggregation}

Arbuscular mycorrhizal fungi can facilitate soil aggregation and contribute to soil stability through their extensive hyphae system $(50 ; 51 ; 37)$. A hypothetical framework based on the aggregate hierarchy hypothesis $(63 ; 46)$ in coupled with a "life cycle" conceptual model $(58)$ describes the involvement of AMF hyphae in the soil aggregation process. Namely, macro-aggregates (250-2500 $\mu \mathrm{m}$ in diameter) are formed first and hyphal enmeshment helps to stabilize the macro-aggregates (50; $51 ; 37$; Fig. 1). This is followed by the formation of micro-aggregates $(<250 \mu \mathrm{m})$ within macroaggregates with the aid of biological binding agents, including glomalin-related soil proteins which is produced by the hyphal of $\operatorname{AMF}(58 ; 57 ; 15$; Fig. 1). Using a stable isotope-tracing technique, an 
0

incubation study provided direct evidence to confirm the process of residue retention within macroaggregates (48). The study shows that macro-aggregates are formed initially and enriched in ${ }^{13} \mathrm{C}$ and ${ }^{15} \mathrm{~N}$ when ${ }^{13} \mathrm{C}-{ }^{15} \mathrm{~N}$-labeled corn residues applied, and then the accumulation of ${ }^{13} \mathrm{C}$ and ${ }^{15} \mathrm{~N}$ continued throughout the incubation. The results show micro-aggregates are enmeshed within macro-aggregates and become highly persistent due to the protection created by spatial effects of occlusion $(58,57 ; 48)$.

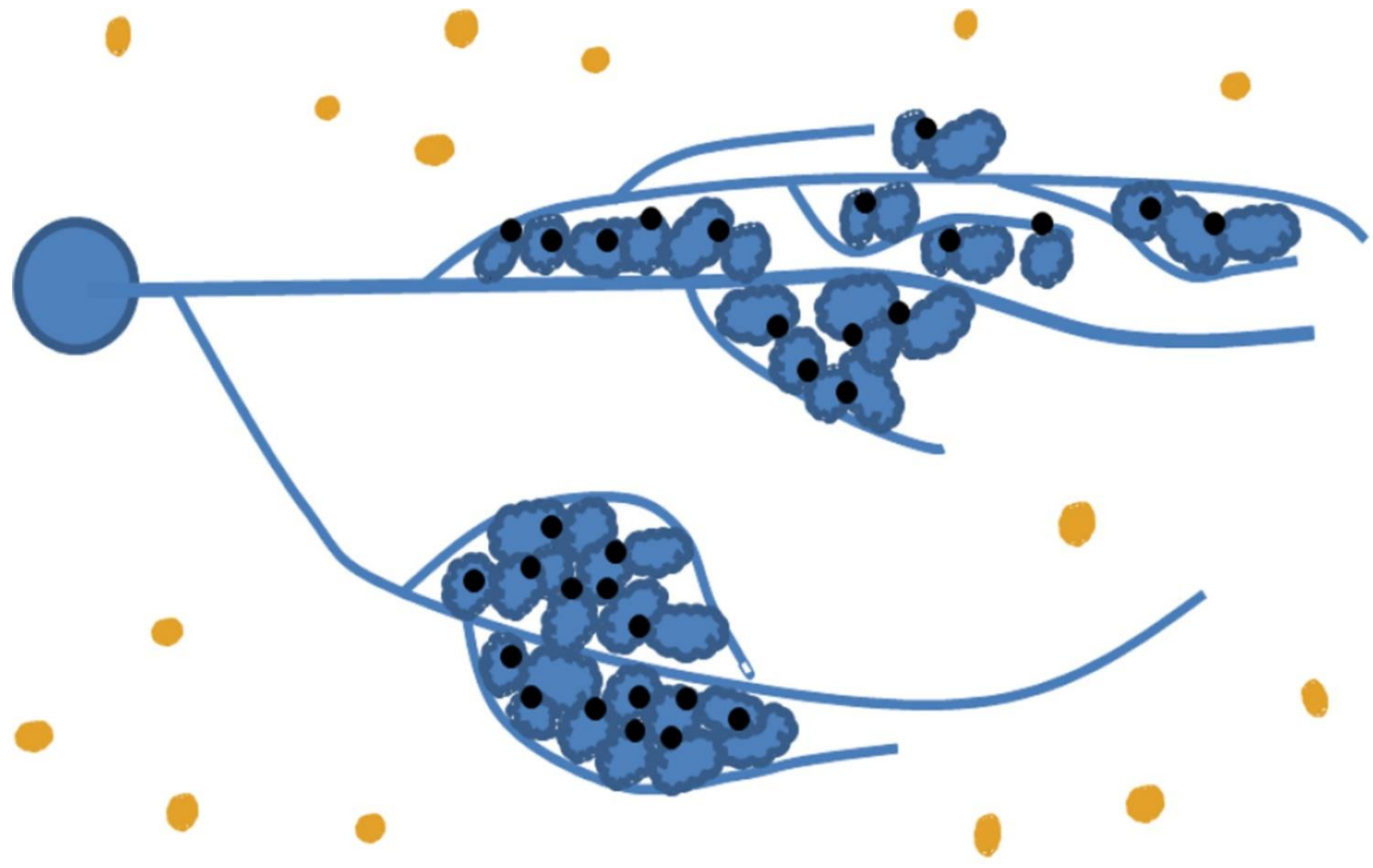

\section{Soil aggregates}

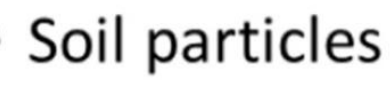

- GRSP

Figure 1. The role of hyphal enmeshment and glomalin-related soil protein (GRSP) in soil aggregation.

The role of AMF in soil aggregation described in this conceptual framework has been also confirmed indirectly by empirical studies. For example, soils with less AMF (i.e., treated with a fungicide) have a significant delay in macro-aggregate formation compared with the untreated soils (30). A long-term (17 and $6 \mathrm{yr}$ ) ecosystem-scale study shows that soil aggregation and $\mathrm{C}$ sequestration 
are tightly correlated with the abundance of AMF in multispecies prairie communities (72). By using a root experiment, a direct positive effect of AMF hyphae on soil aggregate formation has been found (35). Modeling simulation results indicate that AMF combined with organic matter and plant roots are key contributors to aggregate formation in soils (15). These studies and others (e.g., 52; 5; 47) confirm the role of AMF in aggregate formation and persistence.

\section{Stimulation of Organic Carbon Decomposition}

In contrast to traditional understanding of the effect of residue inputs on soil $\mathrm{C}$, recent field experiments find soil $\mathrm{C}$ loss after fresh residues input accompanied by increased hyphae growth (31; 11). However the mechanisms behind these observations are not well described. It has been shown that AMF mycelium can excrete hydrolytic enzymes, such as cellulase, pectinase, and xyloglucanase, but no direct evidence has been presented to show saprotrophic ability $(21 ; 22 ; 67 ; 64)$. Arbuscular mycorrhizal fungi exudates could trigger priming effects, but this is thought to be negligible compared with root exudation and root litter inputs (56). This could suggest that there are indirect mechanisms through which AMF promote organic C decomposition (Fig. 2).

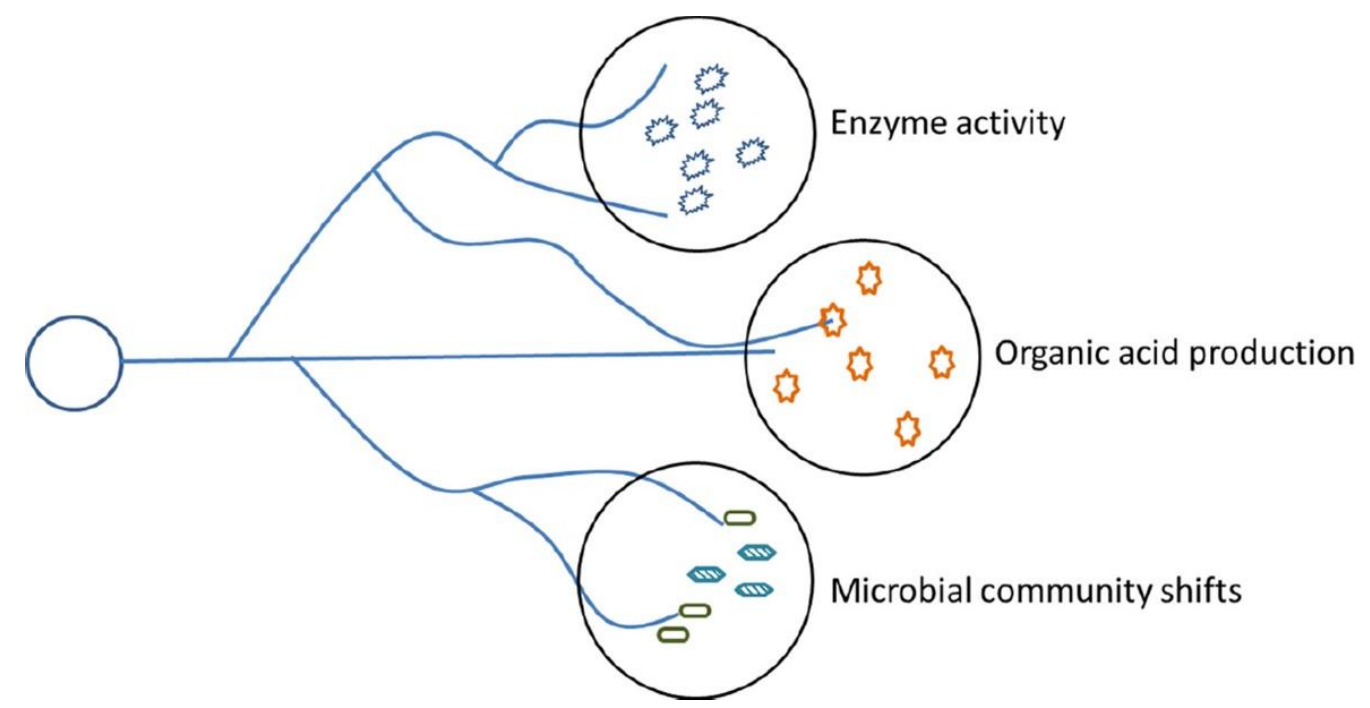

Figure 2. Three proposed pathways via which arbuscular mycorrhizal fungi (AMF) stimulate organic decomposition 
Alkaline phosphatase activity has been shown to increase in leaf litter and soil in the presence of

AMF (33). Another P - related enzyme phosphomonoesterase shows higher activity in the presence of AMF vs. in their absence (45). These may be attributed to external hyphae, which can either directly produce phosphatases or stimulate phosphatase production by other microorganisms (45). In addition, AMF can also modify the composition of plant - derived organic acids. For example, in exudates of Glomus intraradices inoculated roots, significantly higher concentrations of proline and isocitrate are observed than in non - colonized roots (40). Further, the community composition of soil microorganisms could be impacted by AMF through the production of exudates, modification of rhizodeposition products, and alteration of soil structure $(52 ; 3)$.

\section{OPEN QUESTIONS AND DISCUSSION}

In the presence of AMF, C loss commonly increases in the short term following new residue inputs $(31 ; 11)$, whereas the mycorrhizal influence on $\mathrm{C}$ stabilization during litter decomposition is generally persistent over time (68). Therefore, our below discussion will focus on different $\mathrm{C}$ pools potentially affected by AMF.

\section{Different Carbon Pools}

A comparison of litter decomposition between "fresh" and “old" litters (the old litter had been incubated for 3 mo and thus had passed through an initial stage of decomposition) shows that the addition of old residues results in more retention of litter - derived $\mathrm{C}$ and $\mathrm{N}$ in soils compared with the application with fresh residues (68). One possible explanation for this observation comes from model simulation result that suggests that the application of mycorrhizal fungi (mixed ectomycorrhizal and AMF) leads to the increased storage of particulate organic $\mathrm{C}$ over the long - 
139 term (43). This may indicate that the role of AMF in soil C balance may depend on them affecting 140 different $\mathrm{C}$ pools (4). However, the role of nutrients, particularly $\mathrm{P}$, in the litter and soil is rarely 141 considered in these simulation exercises.

142 The increase in the activity of alkaline phosphatase in soil following plant litter application often 143 leads to the suppression of the activity of alkaline phosphatase occurs in the absence of fresh litter, 144 despite the presence of mycorrhiza (33). A recent forest study found that the presence of AMF 145 mycelia increases the activity of phosphomonoesterase in an ingrowth core without leaf litter addition, 146 but not in the presence of new/fresh leaf litter (45). In addition to the change in enzyme activity, AMF 147 can also alter soil microbial community composition during litter decomposition (64). The 148 competition for $\mathrm{C}$ and nutrients can occur between AMF and saprotrophs and between 149 ectomycorrhizal and saprotrophic fungi known as the "Gadgil effect" (19). The presence of AMF 150 leads to a reduction in plant - $\mathrm{C}$ release to soil (20) followed by a reduction in nutrient availability to 151 saprotrophs due to the intensified competition for C and nutrients by AMF (55). Other studies support 152 this observation that AMF suppresses the growth of microbes by competing for nutrients which can 153 lead to the overall slowing of decomposition activity $(31 ; 6)$. For example, AMF can suppress Gram 154 positive and Gram - negative bacteria, and the actinomycetes (27). Further, AMF can prolong 155 decomposition by negatively affecting decomposers overall through competition for limited resources 156 (27). These results suggest that AMF stimulate the decomposition of fresh residue, while suppressing 157 the decomposition of old residue and soil C (Fig. 3). 


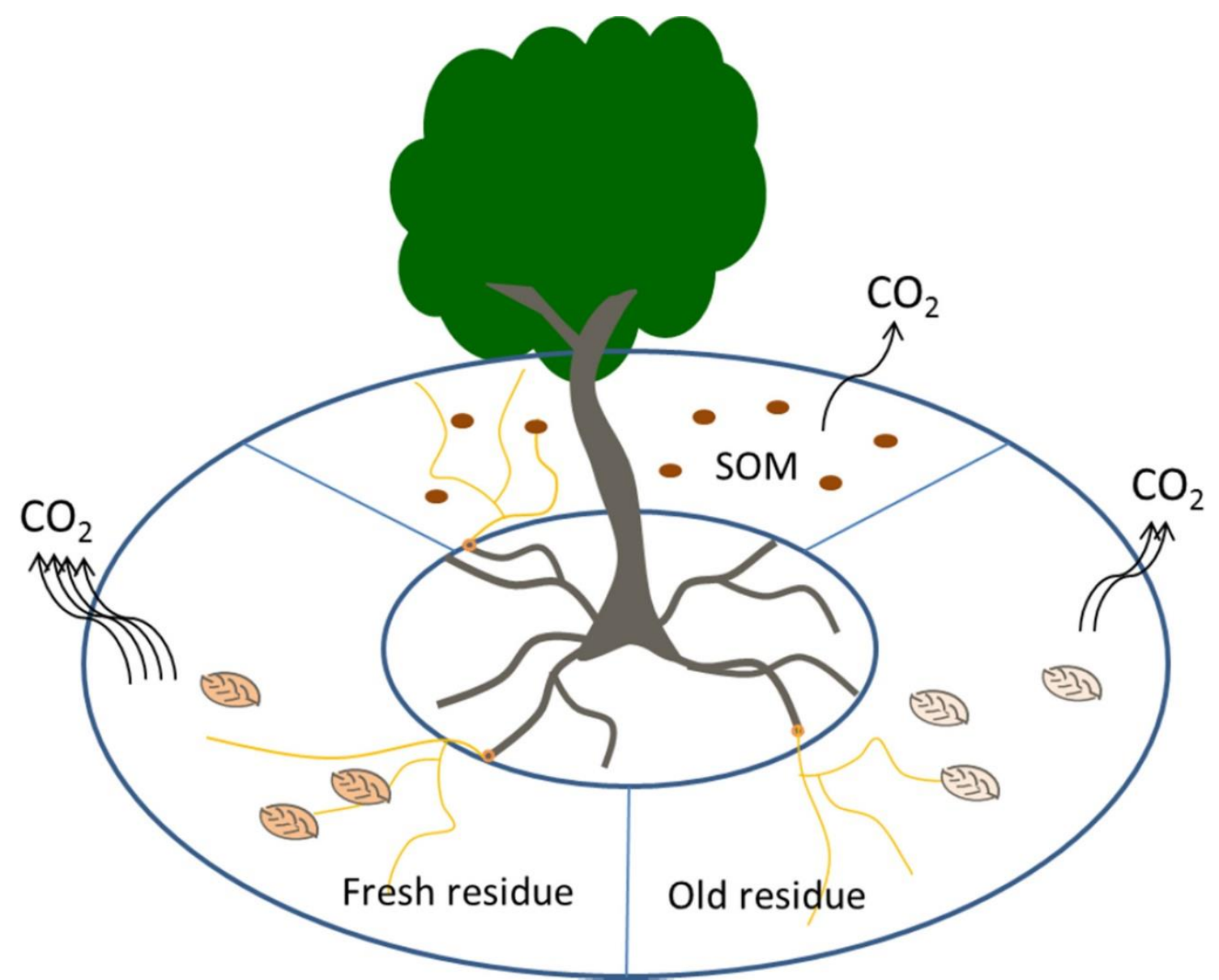

Figure 3. Conceptual diagram of the differential roles of arbuscular mycorrhizal fungi (AMF) in organic decomposition of different carbon pools: fresh residue, old residue, and soil organic matter (SOM).

\section{Carbon/Nitrogen Ratio of Organic Residue}

The quality of plant residues is a controversial topic in describing factors affecting decomposition.

The widely accepted view is that the ratio of $\mathrm{C} / \mathrm{N}$ and/or the labile to recalcitrant fraction is a crucial regulator of decomposition $(12 ; 28)$. Commonly, studies find that AMF stimulation of plant residue decomposition applies both to leaf or fine - root sources $(31 ; 3 ; 36 ; 11)$. However, an increase in soil aggregation and $\mathrm{C}$ retention was demonstrated for woody plant litter decomposition compared to leaf litter (35). A likely explanation for the results is that a higher proportion of recalcitrant compounds such as cellulose and lignin in the woody structures compared to leaf litter (42) could contribute to the occluded particulate fraction within aggregates. In addition, microorganism uses the labile 
fraction more efficiently than the recalcitrant fraction (56) preferentially leaving recalcitrant soil and plant residue $\mathrm{C}$ sources alone. Therefore, the fate of plant residue $\mathrm{C}$ in the presence of AMF also depends on whether fresh organic residues have the opportunity to be decomposed or to be incorporated into soil aggregates. Recalcitrant residues slow the decomposition rate in the absence of available soil resources and allows for a greater probability of occluding particulate $\mathrm{C}$ within aggregates (70).

Some modeling studies indicate that recalcitrant materials are not necessary for soil organic matter formation (18). These studies indicate that some fast - cycling fractions of soil organic matter are comprised of a mixture of plant compounds that include plant lignin and carbohydrates (16). There has no clear explanation for this phenomenon, but it may be related to the high $\mathrm{N}$ demand of AMF (32). Experimental work has increasingly demonstrated that AMF hyphae preferentially colonize decomposing organic patches and to acquire $\mathrm{N}$ directly from the decomposing materials $(31 ; 3 ; 36)$. The $\mathrm{N}$ acquisition from organic materials can account for up to $31 \%$ of fungal $\mathrm{N}$ (32). In support of high $\mathrm{N}$ demand, it is shown that arginine - $\mathrm{N}$ transport in the mycelium (23) and a mycorrhiza specific ammonium transporter are preferentially activated in AMF hyphae (26). More recent evidence indicates that the $\mathrm{N}$ needed by AMF can be used preferentially before being transferred to its plant host (32). Accordingly, hyphae may stimulate decomposition irrespective of the ratio of labile to recalcitrant residues when $\mathrm{N}$ is limiting. For example, a lignin - degrading enzyme was found to be positively correlated with mycorrhizal biomass and AMF may promote lignin degradation to access $\mathrm{N}(39)$.

These results are supported partly by the observation that high soil $\mathrm{N}$ availability reduces the development of AMF extraradical hyphae (41). This can be associated with the obligate need for C from associated plant roots, which allows mycorrhizal fungi to forego the need for $\mathrm{C}$ from soils to build their own biomass (59). This has led to the acceptance and conclusion that $\mathrm{C}$ - rich and nutrient - poor compound, such as cellulose, would not to be degraded by mycorrhizal fungi. This is 
also supported by the negative correlation of AMF spore density with the activity of $\beta$ - glucosidase (which is involved in cellulose decomposition) and the content of soil organic C (14). A decline in mycorrhizal mycelial abundance and an increase in free - living saprotrophic fungi when hyphal connections to roots are severed suggest that mycorrhizae have the ability to repress $\mathrm{C}$ availability to free - living microbes that can compete with ectomycorrhizal fungi (38). However, the relationship between AMF and cellulose decomposition vary with AMF species. Cellulose can increase the amount of external mycelium of G. intraradices and G. mosseae but conversely the decrease in hyphal growth and P uptake by G. intraradices was also found (49). The decomposition of cellulose is time dependent. Cellulose reduces the growth of AMF initially, then increases growth over a longer time period (25). The increased AMF growth with cellulose amendment may be related to a priming effect of saprotrophic microorganisms that solubilize inorganic nutrients, which is essential for AMF hyphal growth (71). Secondary metabolites produced by microorganisms during decomposition of cellulose can also be a contributor to AMF growth (24). These synergistic decomposer/resource availability outcomes influence the maintenance and growth of the entire microbial community and are often overlooked in microbial interaction studies. Future research should address these dependencies of resource availability of different microbial groups during the decomposition process.

\section{Elevated Carbon Dioxide Effects}

The effects of $\mathrm{eCO}_{2}$ on microbial processes have attracted a lot of interest from researchers. Many studies have looked into the growth and proliferation of $\mathrm{AMF}$ under $\mathrm{eCO}_{2}$, and found a consistent positive response of $\mathrm{AMF}$ to $\mathrm{eCO}_{2}$ despite the varied responses among different genera of $\mathrm{AMF}$ (53; $65 ; 11)$. The $\mathrm{AMF}$ response to $\mathrm{eCO}_{2}$ is often the production of a significantly higher number of spores, development of significantly longer hyphal lengths, and increasing colonization of roots (34). Some genera show higher spore number and hyphal lengths but not an increase in the colonization rate (34). 
222 Comparatively, total mycorrhizal biomass may be a stronger indicator for $\mathrm{eCO}_{2}$ effect than 223 colonization rate, because colonization rate is related both with mycorrhizal fungi and root length 224 which can be increased proportionally under $\mathrm{eCO}_{2}$ (65). A meta - analysis indicates that total biomass 225 of AMF can be increased approximately $50 \%$ under $\mathrm{eCO}_{2}(65)$. Carbon dioxide enrichment strongly 226 affects external hyphae compared to the internal hyphae, indicating that it promotes $\mathrm{C}$ allocation to 227 the external AMF hyphal biomass $(54 ; 61 ; 2)$. Therefore, it is expected that $\mathrm{eCO}_{2}$ will likely affect 228 AMF outcomes in controlling soil $\mathrm{C}$ dynamics.

229 Elevated $\mathrm{CO}_{2}$ effects on the decomposition of fresh litters vary mainly with litter quality and soil 230 nutrient regimes $(13 ; 7)$. A meta - analysis including the data from field experiments shows no 231 consistent pattern in either mass loss or respiration rates from litter produced under $\mathrm{eCO}_{2}$ compared 232 to litter from ambient $\mathrm{CO}_{2}$ conditions (44). Whatever positively or negatively affects fresh litter 233 decomposition by $\mathrm{eCO}_{2}$, the increased rhizodeposits under $\mathrm{eCO}_{2}$ could lead to an acceleration of soil 234 microbial growth and decomposition of older soil organic $\mathrm{C}$ fractions (i.e., “the priming effect” ) 235 regardless of nutrient availability $(1 ; 8 ; 69)$. In the presence of AMF, both short - term microcosm 236 experiment and field studies show that $\mathrm{eCO}_{2}$ enhances the decomposition of soil organic $\mathrm{C}$ with varied 237 responses among different AMF species (11). These studies also find that $\mathrm{eCO}_{2}$ significantly 238 increases AMF colonization with fine roots and their hyphae in bulk soil, resulting in a considerable reduction of total $\mathrm{N}$ within hyphae - ingrowth bags and cores and a synchronal increase in plant $\mathrm{N}$, 240 which may be because by the $\mathrm{eCO}_{2}$ effects, namely the scavenging of $\mathrm{N}$ by AMF (11). Therefore, the 241 amount of available soil $\mathrm{N}$ is likely a major outcome in mediating belowground $\mathrm{C}$ turnover under the 242 interactive effects of $\mathrm{eCO}_{2}$ on $\mathrm{AMF}$.

243 When mineral nutrients are available, $\mathrm{eCO}_{2}$ can reduce priming effects, because soil 244 microorganisms shift from consuming older soil organic C pools to utilizing easily degraded 245 rhizodeposits (7). The presence of $\mathrm{AMF}$ enhance the suppression of $\mathrm{eCO}_{2}$ on the decomposition of 246 soil organic C, but such suppression is reduced when AMF community is absent (9), indicating that 
247 the $\mathrm{AMF}$ influence under $\mathrm{eCO}_{2}$ promotes $\mathrm{C}$ storage. When soil $\mathrm{C}$ pools are partitioned into particulate 248 organic matter and mineral - bound $\mathrm{C}$ pools, $\mathrm{eCO}_{2}$ significantly enhances the breakdown of soil 249 particulate organic matter and increases mineral - bound C pools (7). Due to lack of the studies that 250 partition soil $\mathrm{C}$ pools into particulate organic matter and mineral - bound C pools in the presence of 251 AMF, how AMF interactively affect with $\mathrm{eCO}_{2}$ on these soil $\mathrm{C}$ pools is not well characterized, which 252 warrants further investigation. Overall, $\mathrm{eCO}_{2}$ could enhance fresh residue decomposition, priming 253 effect, and soil aggregate formation through promoting AMF growth and their colonization (Fig. 4).

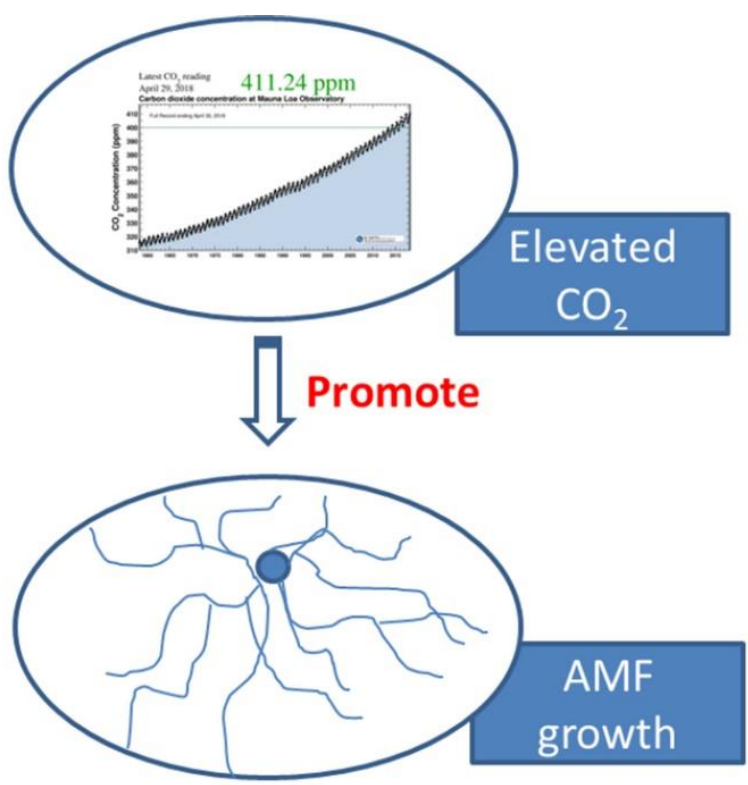

Enhance

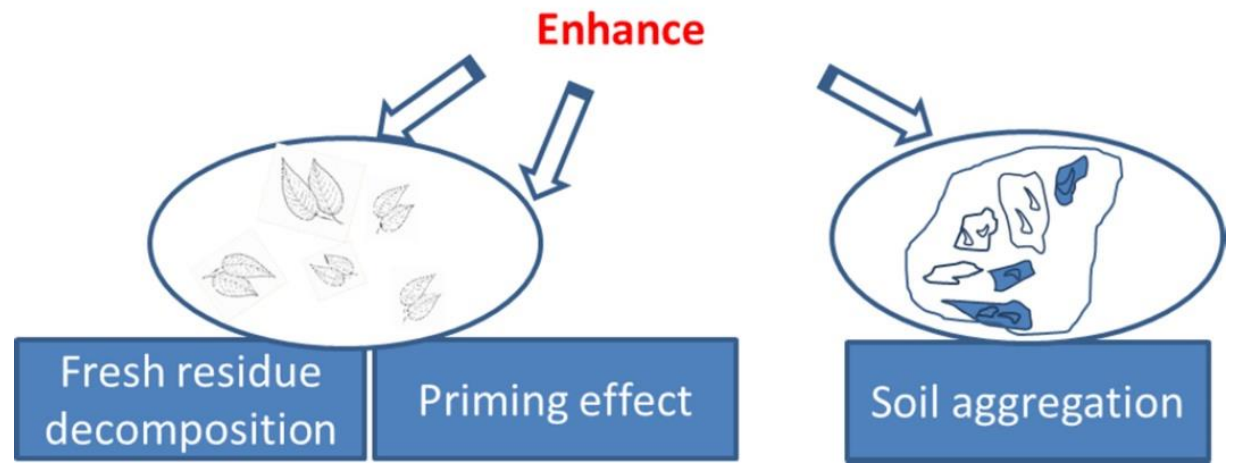

255 Figure 4. The hypothetical relationships between elevated $\mathrm{CO}_{2}$, arbuscular mycorrhizal fungi (AMF), priming 256 effect or soil aggregation. (The $\mathrm{CO}_{2}$ curve was cited from the Scripps Institution of Oceanography at the Mauna 257 Loa Observatory in Hawaii; The conceptual framework of soil aggregation was modified from 58). 
261 The role of AMF in regulation of soil $\mathrm{C}$ dynamics is $\mathrm{C}$ pool dependent. Stimulation of fresh residue 262 decomposition occurs only in the short term following in the presence of labile or $\mathrm{N}$ - rich fresh 263 residues, whereas in the longer term, AMF tend to promote the retention of organic $\mathrm{C}$ into soil 264 aggregates. It should be noted that our discussion does not include the effect of the turnover of AMF 265 hyphae. The turnover of extra - radical mycelium of AMF is commonly rapid (live only 5 - $6 \mathrm{~d} ; 62$ ), 266 thereby mycorrhizae may act as a substantial pathway of $\mathrm{C}$ flow to the soil. Despite potential to 267 sequester soil $\mathrm{C}$ by $\mathrm{AMF}$, studies show that most of the $\mathrm{C}$ in the hyphae is rapidly recycled back to 268 the atmosphere (62). Therefore, this C loss can be underestimated. To quantify the specific 269 contributions of AMF in soil C dynamics, we strongly suggest that studies on organic C 270 decomposition should take into account the time scales, the proximate constituent, and $\mathrm{N}$ content of 271 plant residues. Finally, synergistic outcomes of decomposer/resource availability influences AMF 272 biomass and colonization through affecting the maintenance and growth of the entire microbial 273 community. Future research should address the effect of resource availability on the performance of 274 different microbial groups during the decomposition process that affect AMF.

\section{ACKNOWLEDGMENTS}

The authors kindly thank the technical assistance of Dr. Zhiping Ruan and Ms. Yiran Dong. This research was supported by National Natural Science Foundation of China (31570400).

\section{REFERENCES}

1 Allard, V., Robin, C., Newton, P.C.D., Lieffering, M., and Soussana, J.F.. 2006. Short and longterm effects of elevated $\mathrm{CO}_{2}$ on Lolium perenne rhizodeposition and its consequences on soil organic 
matter turnover and plant $\mathrm{N}$ yield. Soil Biol. Biochem. 38 (6): 1178- 1187. doi: https://doi.org/10.1016/j.soilbio.2005.10.002

2 Antoninka, A., Reich, P.B., and Johnson, N.C.. 2011. Seven years of carbon dioxide enrichment, nitrogen fertilization and plant diversity influence arbuscular mycorrhizal fungi in a grassland ecosystem. New Phytol. 192 (1): 200-214. doi: https://doi.org/10.1111/j.1469-8137.2011.03776.x

3 Atul-Nayyar, A., Hamel, C., Hanson, K., and Germida, J.. 2009. The arbuscular mycorrhizal symbiosis links N mineralization to plant demand. Mycorrhiza 19 (4): 239- 246. doi: https://doi.org/10.1007/s00572-008-0215-0

4 Ball, B.A., Carrillo, Y., and Molina, M.. 2014. The influence of litter composition across the littersoil interface on mass loss, nitrogen dynamics and the decomposer community. Soil Biol. Biochem. 69: 71- 82. doi: https://doi.org/10.1016/j.soilbio.2013.10.048

5 Bedini, S., Avio, L., Sbrana, C., Turrini, A., Migliorini, P., Vazzana, C., and Giovannetti, M.. 2013. Mycorrhizal activity and diversity in a long-term organic Mediterranean agroecosystem. Biol. Fertil. Soils 49 (7): 781- 790. doi: https://doi.org/10.1007/s00374-012-0770-6

6 Brooks, D.D., Chan, R., Starks, E.R., Grayston, S.J., and Jones, M.D.. 2011. Ectomycorrhizal hyphae structure components of the soil bacterial community for decreased phosphatase production. FEMS Microbiol. Ecol. 76: 245-255. doi: https://doi.org/10.1111/j.1574-6941.2011.01060.x 7 Cardon, Z.G., Hungate, B.A., Cambardella, C.A., Chapin, F.S. III, Field, C.B., Holland, E.A., and Mooney, H.A.. 2001. Contrasting effects of elevated $\mathrm{CO}_{2}$ on old and new soil carbon pools. Soil Biol. Biochem. 33 (3): 365- 373. doi: https://doi.org/10.1016/S0038-0717(00)00151-6

8 Carney, K.M., Hungate, B.A., Drake, B.G., and Megonigal, J.P.. 2007. Altered soil microbial community at elevated $\mathrm{CO}_{2}$ leads to loss of soil carbon. Proc. Natl. Acad. Sci. USA 104 (12): 49904995. doi: https://doi.org/10.1073/pnas.0610045104 
3089 Carrillo, Y., Dijkstra, F.A., Le Cain, D., and Pendall, E.. 2016. Mediation of soil C decomposition 309 by arbuscular mycorrizhal fungi in grass rhizospheres under elevated $\mathrm{CO}_{2}$. Biogeochemistry 127 (1): 310 45- 55. doi: https://doi.org/10.1007/s10533-015-0159-3

31110 Cavagnaro, T.R., Bender, S.F., Asghari, H.R., and van der Heijden, M.G.A.. 2015. The role of 312 arbuscular mycorrhizas in reducing soil nutrient loss. Trends Plant Sci. 20 (5): 283- 290. doi: 313 https://doi.org/10.1016/j.tplants.2015.03.004

31411 Cheng, L., Booker, F.L., Tu, C., Burkey, K.O., Zhou, L., and Shew, H.D. et al 2012. Arbuscular 315 mycorrhizal fungi increase organic carbon decomposition under elevated $\mathrm{CO}_{2}$. Science (Washington, 316 DC) 337 (6098): 1084- 1087. doi: https://doi.org/10.1126/science.1224304

31712 Cornwell, W.K., Cornelissen, J.H., Amatangelo, K., Dorrepaal, E., Eviner, V.T., and Godoy, O. 318 et al 2008. Plant species traits are the predominant control on litter decomposition rates within biomes 319 worldwide. Ecol. Lett. 11 (10): 1065- 1071. doi: https://doi.org/10.1111/j.1461-0248.2008.01219.x 32013 Cotrufo, M.F., Briones, M.J.I., and Ineson, P.. 1998. Elevated $\mathrm{CO}_{2}$ affects field decomposition 321 rate and palatability of tree leaf litter: Importance of changes in substrate quality. Soil Biol. Biochem. 30 (12): 1565- 1571. doi: https://doi.org/10.1016/S0038-0717(98)00032-7

14 Delelegn, Y.T., Purahong, W., Blazevic, A., Yitaferu, B., Wubet, T., Göransson, H., and Godbold, D.L.. 2017. Changes in land use alter soil quality and aggregate stability in the highlands of northern 325 Ethiopia. Sci. Rep. 7 (1):article 13602. doi: https://doi.org/10.1038/s41598-017-14128-y 15 Daynes, C.N., Field, D.J., Saleeba, J.A., Cole, M.A., and McGee, P.A.. 2013. Development and stabilisation of soil structure via interactions between organic matter, arbuscular mycorrhizal fungi and plant roots. Soil Biol. Biochem. 57: 683- 694. doi: https://doi.org/10.1016/j.soilbio.2012.09.020 32916 Derrien, D., and Amelung, W.. 2011. Computing the mean residence time of soil carbon fractions 330 using stable isotopes, impacts of the model framework. Eur. J. Soil Sci. 62: 237- 252. doi: https://doi.org/10.1111/j.1365-2389.2010.01333.x 
17 Drigo, B., Pijl, A.S., Duyts, H., Kielak, A.M., Gamper, H.A., and Koutekamer, M.J. et al 2010.

Shifting carbon flow from roots into associated microbial communities in response to elevated atmospheric $\mathrm{CO}_{2}$. Proc. Natl. Acad. Sci. USA 107: 10938- 10942. doi: https://doi.org/10.1073/pnas.0912421107

18 Dungait, J.A.J., Hopkins, D.W., Gregory, A.S., and Whitmore, A.P.. 2012. Soil organic matter turnover is governed by accessibility not recalcitrance. Glob. Change Biol. 18 (6): 1781-1796. doi: https://doi.org/10.1111/j.1365-2486.2012.02665.x

19 Fernandez, C.W., and Kennedy, P.G.. 2016. Revisiting the 'Gadgil effect': Do interguild fungal interactions control carbon cycling in forest soils? New Phytol. 209 (4): 1382- 1394. doi: https://doi.org/10.1111/nph.13648

20 Fitter, A.H., Graves, J.D., Watkins, N.K., Robinson, D., and Scrimgeour, C.. 1998. Carbon transfer between plants and its control in networks of arbuscular mycorrhizas. Funct. Ecol. 12: 406-412. doi: https://doi.org/10.1046/j.1365-2435.1998.00206.x

21 García-Romera, I., García-Garrido, J.M., Martinez-Molina, E., and Ocampo, J.A.. 1991. Production of pectolytic enzymes in lettuce root colonized by Glomus mosseae. Soil Biol. Biochem. 23 (6): 597- 601. doi: https://doi.org/10.1016/0038-0717(91)90118-4

22 García-Garrido, J.M., García-Romera, I., and Ocampo, J.A.. 1992. Cellulase production by the vesicular-arbuscular mycorrhizal fungus Glomus mosseae (Nicol. \& Gerd.) Gerd. and Trappe. New Phytol 121 (2): 221- 226. doi: https://doi.org/10.1111/j.1469-8137.1992.tb01107.x

23 Govindarajulu, M., Pfeffer, P.E., Jin, H., Abubaker, J., Douds, D.D., and Allen, J.W. et al 2005. Nitrogen transfer in the arbuscular mycorrhizal symbiosis. Nature (London) 435: 819- 823. doi: https://doi.org/10.1038/nature03610

24 Gryndler, M., Hršelová, H., Cajthaml, T., Havránková, M., Řezáčová, V., Gryndlerová, H., and Larsen, J.. 2009. Influence of soil organic matter decomposition on arbuscular mycorrhizal fungi in 
356

357

358

359

360

361

362

363

364

365

366

367

368

369

370

371

372

373

374

terms of asymbiotic hyphal growth and root colonization. Mycorrhiza 19 (4): 255- 266. doi: https://doi.org/10.1007/s00572-008-0217-y

25 Gryndler, M., Vosátka, M., Hršelová, H., Chvátalová, I., and Jansa, J.. 2002. Interaction between arbuscular mycorrhizal fungi and cellulose in growth substrate. Appl. Soil Ecol. 19: 279- 288. doi: https://doi.org/10.1016/S0929-1393(02)00004-5

26 Guether, M., Neuhäuser, B., Balestrini, R., Dynowski, M., Ludewig, U., and Bonfante, P.. 2009. A mycorrhizal-specific ammonium transporter from Lotus japonicus acquires nitrogen released by arbuscular mycorrhizal fungi. Plant Physiol. 150: 73- 83. doi: https://doi.org/10.1104/pp.109.136390 27 Gui, H., Purahong, W., Hyde, K.D., Xu, J., and Mortimer, P.E.. 2017. The arbuscular mycorrhizal fungus Funneliformis mosseae alters bacterial communities in subtropical forest soils during litter decomposition. Front. Microbiol. 8:article 1120. doi: https://doi.org/10.3389/fmicb.2017.01120

28 Hättenschwiler, S., Coq, S., Barantal, S., and Handa, I.T.. 2011. Leaf traits and decomposition in tropical rainforests: Revisiting some commonly held views and towards a new hypothesis. New Phytol. 189 (4): 950- 965. doi: https://doi.org/10.1111/j.1469-8137.2010.03483.x

29 Heimann, M., and Reichstein, M.. 2008. Terrestrial ecosystem carbon dynamics and climate feedbacks. Nature (London) 451: 289- 292. doi: https://doi.org/10.1038/nature06591

30 Helfrich, M., Ludwig, B., Potthoff, M., and Flessa, H.. 2008. Effect of litter quality and soil fungi on macroaggregate dynamics and associated partitioning of litter carbon and nitrogen. Soil Biol. Biochem. 40 (7): 1823- 1835. doi: https://doi.org/10.1016/j.soilbio.2008.03.006

31 Hodge, A., Campbell, C.D., and Fitter, A.H.. 2001. An arbuscular mycorrhizal fungus accelerates decomposition and acquires nitrogen directly from organic material. Nature (London) 413: 297- 299. doi: https://doi.org/10.1038/35095041

32 Hodge, A., and Fitter, A.H.. 2010. Substantial nitrogen acquisition by arbuscular mycorrhizal fungi from organic material has implications for N cycling. Proc. Natl. Acad. Sci. USA 107: 13754- 13759. doi: https://doi.org/10.1073/pnas.1005874107 
38133 Joner, E.J., and Jakobsen, I.. 1995. Growth and extracellular phosphatase activity of arbuscular 382 mycorrhizal hyphae as influenced by soil organic matter. Soil Biol. Biochem. 27: 1153- 1159. doi: 383 https://doi.org/10.1016/0038-0717(95)00047-I

38434 Klironomos, J.N., Ursic, M., Rillig, M., and Allen, M.F.. 1998. Interspecific differences in the 385 response of arbuscular mycorrhizal fungi to Artemisia tridentata grown under elevated atmospheric $386 \mathrm{CO}_{2}$. New Phytol. 138 (4): 599-605. doi: https://doi.org/10.1046/j.1469-8137.1998.00141.x

38735 Leifheit, E.F., Verbruggen, E., and Rillig, M.C.. 2015. Arbuscular mycorrhizal fungi reduce 388 decomposition of woody plant litter while increasing soil aggregation. Soil Biol. Biochem. 81: 323389 328. doi: https://doi.org/10.1016/j.soilbio.2014.12.003

39036 Leigh, J., Hodge, A., and Fitter, A.H.. 2009. Arbuscular mycorrhizal fungi can transfer substantial 391 amounts of nitrogen to their host plant from organic material. New Phytol. 181 (1): 199- 207. doi: 392 https://doi.org/10.1111/j.1469-8137.2008.02630.x

39337 Lehmann, J., and Kleber, M.. 2015. The contentious nature of soil organic matter. Nature (London) $394 \quad 528: 60-68$.

39538 Lindahl, B.D., de Boer, W., and Finlay, R.D.. 2010. Disruption of root carbon transport into forest 396 humus stimulates fungal opportunists at the expense of mycorrhizal fungi. ISME J. 4: 872- 881. doi: 397 https://doi.org/10.1038/ismej.2010.19

39839 Lindahl, B.D., and Tunlid, A.. 2015. Ectomycorrhizal fungi-potential organic matter decomposers, 399 yet not saprotrophs. New Phytol. 205 (4): 1443-1447. doi: https://doi.org/10.1111/nph.13201 40040 Lioussanne, L., Jolicoeur, M., and St-Arnaud, M.. 2008. Mycorrhizal colonization with Glomus 401 intraradices and development stage of transformed tomato roots significantly modify the chemotactic 402 response of zoospores of the pathogen Phytophthora nicotianae. Soil Biol. Biochem. 40: 2217- 2224. 403 doi: https://doi.org/10.1016/j.soilbio.2008.04.013 
40441 Liu, A., Hamel, C., Hamilton, R.I., and Smith, D.L. 2000. Mycorrhizae formation and nutrient 405 uptake of new corn (Zea mays L.) hybrids with extreme canopy and leaf architecture as influenced 406 by soil N and P levels. Plant Soil 221 (2): 157- 166. doi: https://doi.org/10.1023/A:1004777821422 40742 McLellan, T.M., Aber, J.D., Martin, M.E., Melillo, J.M., and Nadelhoffer, K.J.. 1991. 408 Determination of nitrogen, lignin, and cellulose content of decomposing leaf material by near infrared 409 reflectance spectroscopy. Can. J. For. Res. 21 (11): 1684- 1688. doi: https://doi.org/10.1139/x91-232 41043 Moore, J.A., Jiang, J., Patterson, C.M., Mayes, M.A., Wang, G., and Classen, A.T.. 2015. 411 Interactions among roots, mycorrhizas and free-living microbial communities differentially impact 412 soil carbon processes. J. Ecol. 103: 1442- 1453. doi: https://doi.org/10.1111/1365-2745.12484

41344 Norby, R.J., Cotrufo, M.F., Ineson, P., O'Neill, E.G., and Canadell, J.G.. 2001. Elevated CO 2 , litter 414 chemistry, and decomposition: A synthesis. Oecologia 127 (2): $153-165$. doi: 415 https://doi.org/10.1007/s004420000615

41645 Nottingham, A.T., Turner, B.L., Winter, K., Chamberlain, P.M., Stott, A., and Tanner, E.V.. 2013. 417 Root and arbuscular mycorrhizal mycelial interactions with soil microorganisms in lowland tropical 418 forest. FEMS Microbiol. Ecol. 85: 37- 50. doi: https://doi.org/10.1111/1574-6941.12096

41946 Oades, J.M. 1984. Soil organic matter and structural stability, mechanisms and implications for 420 management. Plant Soil 76: 319-337. doi: https://doi.org/10.1007/BF02205590

42147 Peng, S., Guo, T., and Liu, G.. 2013. The effects of arbuscular mycorrhizal hyphal networks on 422 soil aggregations of purple soil in southwest China. Soil Biol. Biochem. 57: 411- 417. doi: 423 https://doi.org/10.1016/j.soilbio.2012.10.026

42448 Poirier, V., Angers, D.A., and Whalen, J.K.. 2014. Formation of millimetric-scale aggregates and 425 associated retention of $13 \mathrm{C}-15 \mathrm{~N}$-labelled residues are greater in subsoil than topsoil. Soil Biol. 426 Biochem. 75: 45- 53. doi: https://doi.org/10.1016/j.soilbio.2014.03.020 
49 Ravnskov, S., Larsen, J., Olsson, P.A., and Jakobsen, I.. 1999. Effects of various compounds on growth and phosphorus uptake of an arbuscular mycorrhizal fungus. New Phytol. 141: 517- 524. doi: https://doi.org/10.1046/j.1469-8137.1999.00353.x

50 Rillig, M.C. 2004. Arbuscular mycorrhizae, glomalin, and soil aggregation. Can. J. Soil Sci. 84: 355- 363. doi: https://doi.org/10.4141/S04-003

51 Rillig, M.C., Mardatin, N.F., Leifheit, E.F., and Antunes, P.M.. 2010. Mycelium of arbuscular mycorrhizal fungi increases soil water repellency and is sufficient to maintain water-stable soil aggregates. Soil Biol. Biochem. 42: 1189- 1191. doi: https://doi.org/10.1016/j.soilbio.2010.03.027 52 Rillig, M.C., Mummey, D.L., Ramsey, P.W., Klironomos, J.N., and Gannon, J.E.. 2006. Phylogeny of arbuscular mycorrhizal fungi predicts community composition of symbiosis-associated bacteria. FEMS Microbiol. Ecol. 57 (3): 389- 395. doi: https://doi.org/10.1111/j.15746941.2006.00129.x

53 Rillig, M.C., Treseder, K.K., and Allen, M.F.. 2002. Global change and mycorrhizal fungi In: M.G.A. Heijden, and I. Sanders, editors, Mycorrhizal ecology. Springer, Berlin, Germany. p. 135160. doi: https://doi.org/10.1007/978-3-540-38364-2_6

54 Sanders, I.R., Streitwolf-Engel, R., Van der Heijden, M.G.A., Boller, T., and Wiemken, A.. 1998. Increased allocation to external hyphae of arbuscular mycorrhizal fungi under $\mathrm{CO}_{2}$ enrichment. Oecologia 117 (4): 496- 503. doi: https://doi.org/10.1007/s004420050685

55 Schimel, J.P., and Bennett, J.. 2004. Nitrogen mineralization: Challenges of a changing paradigm. Ecology 85: 591-602. doi: https://doi.org/10.1890/03-8002

56 Shahzad, T., Chenu, C., Genet, P., and Barot, S.. 2015. Contribution of exudates, arbuscular mycorrhizal fungi and litter depositions to the rhizosphere priming effect induced by grassland species. Soil Biol. Biochem. 80: 146- 155. doi: https://doi.org/10.1016/j.soilbio.2014.09.023 
45057 Six, J., Bossuyt, H., Degryze, S., and Denef, K.. 2004. A history of research on the link between 451 (micro) aggregates, soil biota, and soil organic matter dynamics. Soil Tillage Res. 79 (1): 7- 31. doi: 452 https://doi.org/10.1016/j.still.2004.03.008

453

454 455 456 457 458 459 460 461 462 463 464 465 466 467 468 469 470 471 472 473 474

58 Six, J., Elliott, E.T., and Paustian, K.. 2000. Soil macroaggregate turnover and microaggregate formation, a mechanism for $\mathrm{C}$ sequestration under no-tillage agriculture. Soil Biol. Biochem. 32: 2099-2103. doi: https://doi.org/10.1016/S0038-0717(00)00179-6

59 Smith, S.E., and Read, D.J.. 2010. Mycorrhizal symbiosis. Academic Press, San Diego, CA. 60 Soudzilovskaia, N.A., Heijden, M.G.A., Cornelissen, J.H.C., Makarov, M.I., Onipchenko, V.G., and Maslov, M.N. et al 2015. Quantitative assessment of the differential impacts of arbuscular and ectomycorrhiza on soil carbon cycling. New Phytol. 208 (1): 280- 293. doi: https://doi.org/10.1111/nph.13447

61 Staddon, P.L., Gregersen, R., and Jakobsen, I.. 2004. The response of two Glomus mycorrhizal fungi and a fine endophyte to elevated atmospheric $\mathrm{CO}_{2}$, soil warming and drought. Glob Chang Biol. 10 (11): 1909- 1921. doi: https://doi.org/10.1111/j.1365-2486.2004.00861.x

62 Staddon, P.L., Ramsey, C.B., Ostle, N., Ineson, P., and Fitter, A.H.. 2003. Rapid turnover of hyphae of mycorrhizal fungi determined by AMS microanalysis of 14C. Science (Washington, DC) 300: 1138- 1140. doi: https://doi.org/10.1126/science.1084269

63 Tisdall, J.M., and Oades, J.M.. 2006. Organic matter and water stable aggregates in soil. Eur. J. Soil Sci. 33 (2): 141- 163. doi: https://doi.org/10.1111/j.1365-2389.1982.tb01755.x

64 Toljander, J.F., Lindahl, B.D., Paul, L.R., Elfstrand, M., and Finlay, R.D.. 2007. Influence of arbuscular mycorrhizal mycelial exudates on soil bacterial growth and community structure. FEMS Microbiol. Ecol. 61: 295-304. doi: https://doi.org/10.1111/j.1574-6941.2007.00337.x

65 Treseder, K.K. 2004. A meta-analysis of mycorrhizal responses to nitrogen, phosphorus, and atmospheric $\mathrm{CO}_{2}$ in field studies. New Phytol. 164: 347- 355. doi: https://doi.org/10.1111/j.14698137.2004.01159.x 
47566 van der Heijden, M.G.A., Martin, F.M., Selosse, M.A., and Sanders, I.R.. 2015. Mycorrhizal 476 ecology and evolution, the past, the present, and the future. New Phytol. 205 (4): 1406- 1423. doi: 477 https://doi.org/10.1111/nph.13288

47867 Varma, A. 1999. Hydrolytic enzymes from arbuscular mycorrhizae, the current status. Mycorrhiza. 479 Springer, Berlin. p. 373-389. doi: https://doi.org/10.1007/978-3-662-03779-9_15

48068 Verbruggen, E., Jansa, J., Hammer, E.C., and Rillig, M.C.. 2016. Do arbuscular mycorrhizal fungi 481 stabilize litter-derived carbon in soil? J. Ecol. 104 (1): 261- 269. doi: https://doi.org/10.1111/1365$482 \quad 2745.12496$

48369 Vestergård, M., Reinsch, S., Bengtson, P., Ambus, P., and Christensen, S.. 2016. Enhanced 484 priming of old, not new soil carbon at elevated atmospheric $\mathrm{CO}_{2}$. Soil Biol. Biochem. 100: 140- 148. 485 doi: https://doi.org/10.1016/j.soilbio.2016.06.010

48670 von Lützow, M., Kögel-Knabner, I., Ekschmitt, K., Flessa, H., Guggenberger, G., Matzner, E., 487 and Marschner, B.. 2007. SOM fractionation methods: Relevance to functional pools and to 488 stabilization mechanisms. Soil Biol. Biochem. 39 (9): 2183- 2207. doi: 489 https://doi.org/10.1016/j.soilbio.2007.03.007

49071 Welc, M., Ravnskov, S., Kieliszewska-Rokicka, B., and Larsen, J.. 2010. Suppression of other soil 491 microorganisms by mycelium of arbuscular mycorrhizal fungi in root-free soil. Soil Biol. Biochem. 492 42: 1534- 1540. doi: https://doi.org/10.1016/j.soilbio.2010.05.024

49372 Wilson, G.W.T., Rice, C.W., Rillig, M.C., Pringer, A., and Hartmett, D.C.. 2009. Soil aggregation 494 and carbon sequestration are tightly correlated with the abundance of arbuscular mycorrhizal fungi, 495 results from long-term field experiments. Ecol. Lett. 12 (5): 452- 461. doi: 496 https://doi.org/10.1111/j.1461-0248.2009.01303.x 